\title{
Terminology Overload?
}

\section{Terminolojiye Aşıı Yüklenme}

\section{Alan Gilchrist*}

\begin{abstract}
The information industry is now full of professionals from many areas, and those who have been working in that area the longest: that is to say, librarians, documentalists and information scientists, must learn the language that these other professions use if they are to maintain their own professionalism and work effectively (as they must) with the relative newcomers.

The belief in the statement above is exemplified in the new use of the word taxonomy, and several meanings of this word are discussed with reference to findings from a research study conducted by the author.
\end{abstract}

Keywords: Automatic indexing, Information overload, Taxonomy, Automatic classification.

\section{Öz}

Bugün, enformasyon sanayiinde birçok alandan gelen profesyoneller ve bunların arasında bu alanda en çok emek vermiş olan kütüphaneciler, belge ve bilgi bilimciler, eğer kendi profesyonelliklerini sürdürmek ve göreceli olarak bu alana giren yeni kişilerle etkin bir şekilde çalışmak istiyorlarsa, diğer meslekte olanların dilini öğrenmelidirler.

Yukarıda ifade edilen gerçek, "taksonomi" teriminin yeni kullanımına ilişkin bir örnek üzerinde anlatılmış ve yazar tarafından yapılmış olan bir araştırmanın bulgularına dayanarak, bu terimin çeşitlianlamları açıklanmiştır.

Anahtar säzcükler: Mekanik indeksleme, Aşın bilgi yükleme, Taksonomi, Bilgisayarla sınıflama.

\footnotetext{
- Cura Consortium and Senior Associate Consultant, (cura@fastnet.co.uk).
} 


\section{Introduction.}

The word "taxonomy" has now entered the vocabulary of librarianship and documentation; or rather one should say re-entered, as it is a term well understood by librarians, documentalists and information scientists to mean classification, particularly in the context of Linnaeus. It is therefore clear that the word has been introduced by others. Indeed, this seems to be the case and, furthermore, it is by no means the only word that has been introduced into the sphere of information retrieval, a sphere that librarians and information scientists have, for some time, regarded as their own. There are two major factors behind this appropriation (or rewording) of "our" terminology. The first comes with the emergence of Information Management and more recently Knowledge Management with their emphases on the word 'management'. At last, senior management has woken up to the importance of 'information', and so Chief Information Officers and Chief Knowledge OHficers are being appointed in the larger enterprises. However, the former tend to be recruited from the area of Information Technology; and the latter often from Human Relations Development. The second factor is that for some time now, the vendors of software and information (and to some extent hardware) have targeted the end-user market; a far larger and more lucrative market than that represented by the information intermediaries, and this dialogue has introduced yet more neologisms.

Many librarians and documentalists have long recognized, for example, that enterprises would find it sensible to attempt to relate externally purchased information with internally generated information; or that people are prime repositories of information and that when they leave the enterprise, they take that information with them. Senior management now also recognize these two factors; and, unlike the great majority of librarians and documentalists, have the money and the power to do something about it. And in doing something about it, they tend to turn to the information technologists, the software vendors and the management consultants who all bring their own views - and their own terminologies - to the problem. In many ways, this is a good thing. Some of the old and sometimes obstructive professional barriers are coming down, as for example between librarians, documentalists, records managers and corporate archivists; but there is still a long way to go in bring- 
ing these people more closely together to work in more effective partnership with information technologists and senior managers. One of the fundamental problems is that of terminology, of sharing a common language in the workplace. There are some encouraging signs that the skills of librarians and documentalists will not be ignored; so, for example, the well-known portal Yahoo is said to employ some 400 librarians in the task of categorizing the evergrowing numbers of websites (growing at the rate of 7.3 million pages per day!). However, if librarians and documentalists are going to make even more headway, they will have to keep up with a lot of new jargon being coined in the areas of information management, knowledge management and information retrieval. It is not just a simple question of agreeing that an English person should use the word 'sweets' while the American uses "candies'. This "new" word taxonomy, despite the protestations of some librarians is not the same as classification, though it has strong connections. Nor is it, as some would maintain, just another name for thesaurus; though again there are strong connections. What then are taxonomies in the new sense?

\section{Reasons for taxonomies}

The fact that others might introduce old words with new meanings into previously relatively stable domains of discourse should make us think. So, what have been the triggers for this particular development with regard to taxonomies? There are perhaps four obvious factors at work:

- Information overload. Conventional search engines are often now seen to be inadequate in dealing effectively with very large databases, and it is apparent that users need complementary search aids and filters.

- Information literacy. Research has shown that the majority of endusers have severe problems in knowing how to search for information, leading to wasted time and the missing of useful information.

- Organisational terminology. Published classifications and thesauri do not reflect the particular languages of organizations, in which, typically, 80 per cent of the information held has been created internally. 
- "Destructuring" of organisations. Mergers and Acquisitions have created big cultural problems at the implementation stage. Similar problems are found in partnering through extranets, and in the establishment and operation of virtual communities.

\section{Types of taxonomies}

There are, perhaps, four manifestations of taxonomies in the modern sense (discounting the traditional Linnaean classification). These address different issues, or reasons as discussed above; and may be used in combination.

Web directories: These are commonly used on the Web and are, in fact, a form of classification. A menu of top terms is offered to the user. Clicking on a selected term will display a second level, and so on, for several more levels, arriving finally at perhaps some information or references, or the possibility of offering the last selected term to one or more search engines. Each level does not have to be hierarchical in the normally accepted sense, and terms may be repeated at different levels, providing alternative pathways for the searcher.

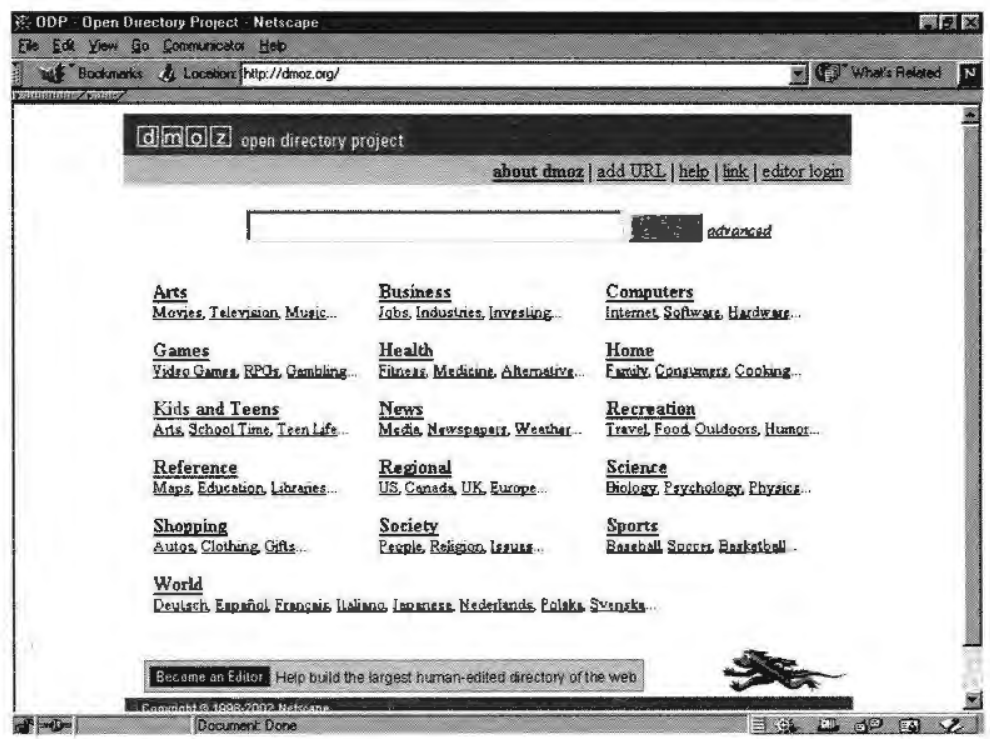

Figure - 1 


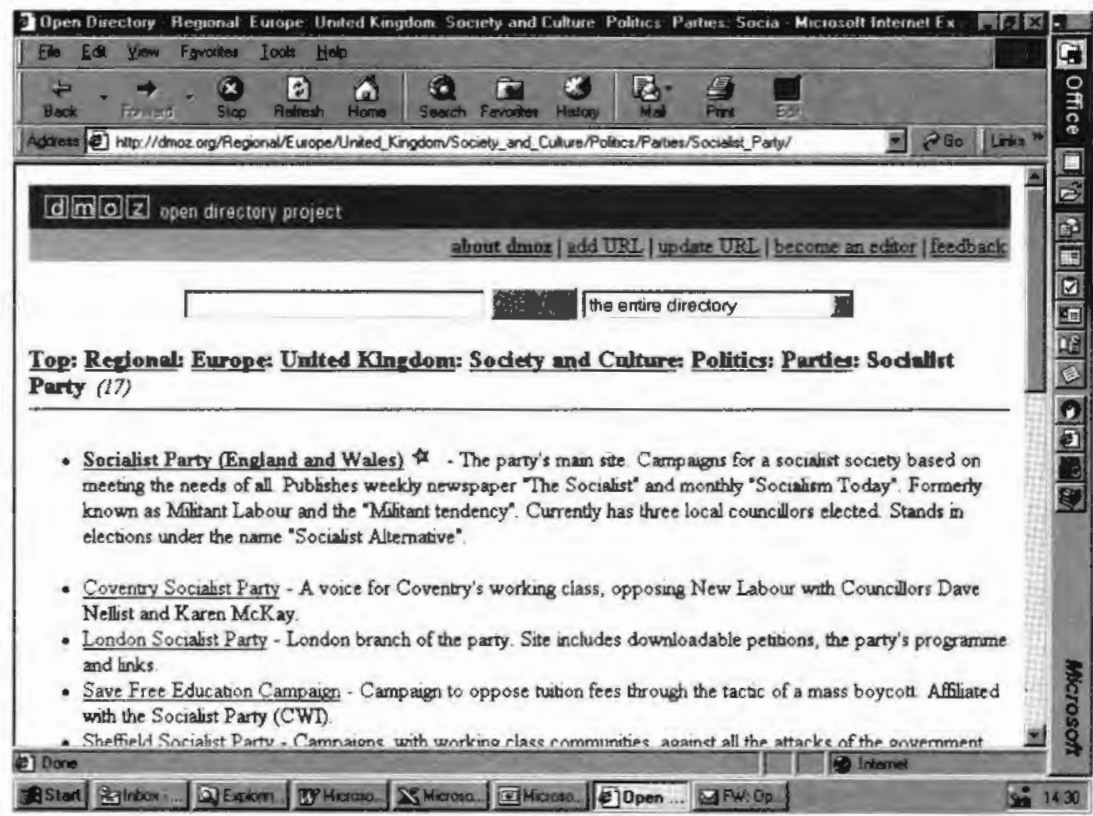

Figure - 2

Common web directories, of which most, or perhaps all, are manually created include The Open Directory (Figs 1 and 2).

Taxonomies to support automatic indexing : In this case, all that the user sees is a shallow classification of typically two levels and perhaps 1000 to 4000 terms in all. What the user does not see is the rules base behind the classification, which contains sets of terms, weights and instructions relating to each term; the rules base being used to automatically extract appropriate index terms, which may, or may not, be present in the documents. This approach is particularly attractive where throughputs are so large that manual indexing is economically impossible. Nevertheless, the compilation of these rules bases is very labour intensive, often taking 4 or 5 hours per term. 


\section{BBC Rules Base}

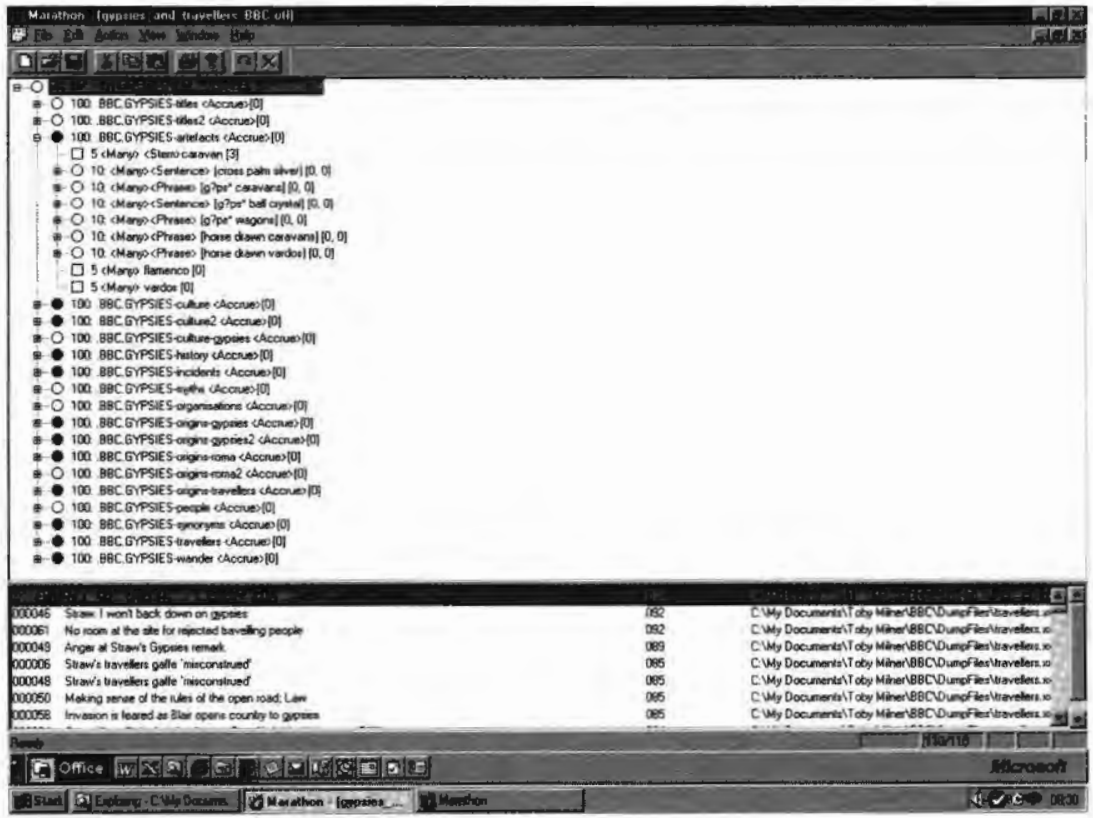

Figure - 3

Figure 3 shows part of a rules base employed by the British Broadcasting Corporation in its NEON (NEws ONline) information retrieval system. This was built by knowledge engineers in the software house Smartlogik, using Infosort programs.

Taxonomies created by automatic categorization : A growing number of software packages are now available which purport to be able to analyse text, to automatically create categories from that analysis and to classify the analysed documents according to the categories created. These categories may then be displayed as web directories (see above) and/or as two- dimensional maps, where related terms are linked to the selected term that appears 
in the middle of the map. Selection of a related term will then move that term to the centre and introduce a new set of related terms. In practice, these packages are effective only when dealing with relatively large collections of conceptually homogeneous material, and when seeded at the beginning of the operation by loading relevant terminologies or glossaries. They also normally require a significant amount of human editing and maintenance.

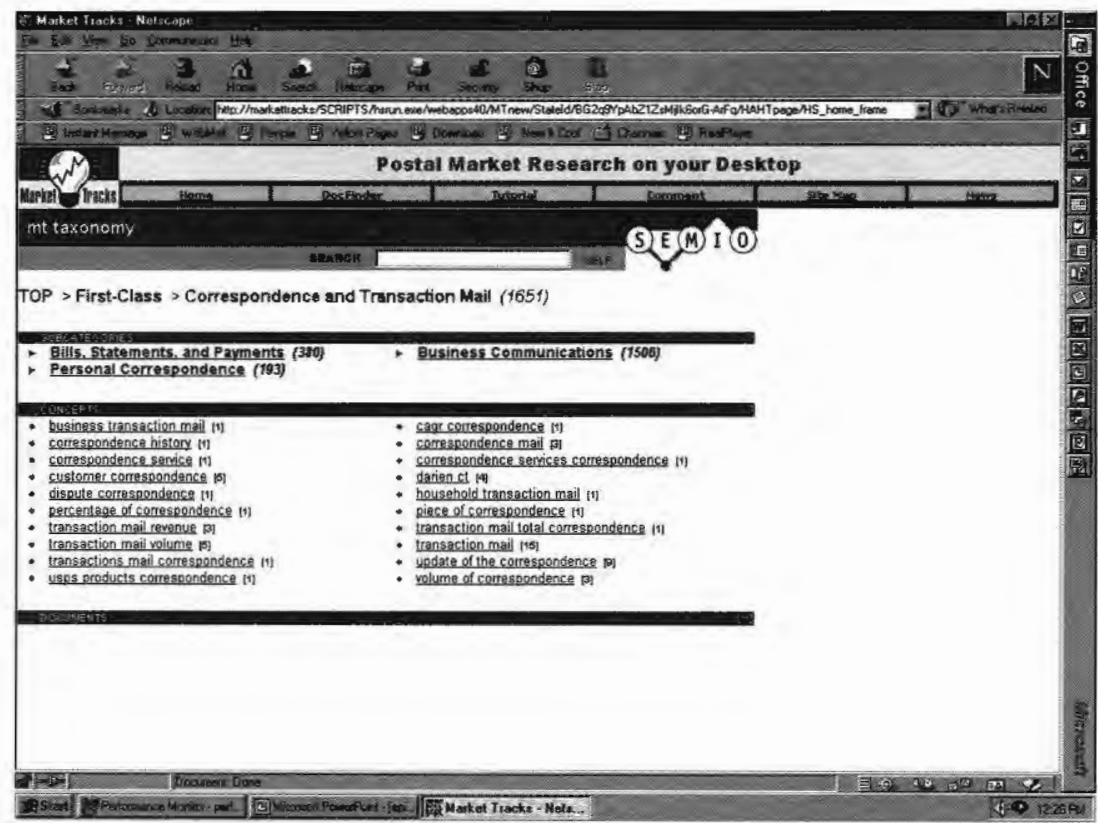

\section{Figure - 4}

Figure 4 shows a web directory menu automatically generated by software supplier Semio from a body of text within the United States Postal Services, internally seeded by loading external and internal glossaries of business terms. 


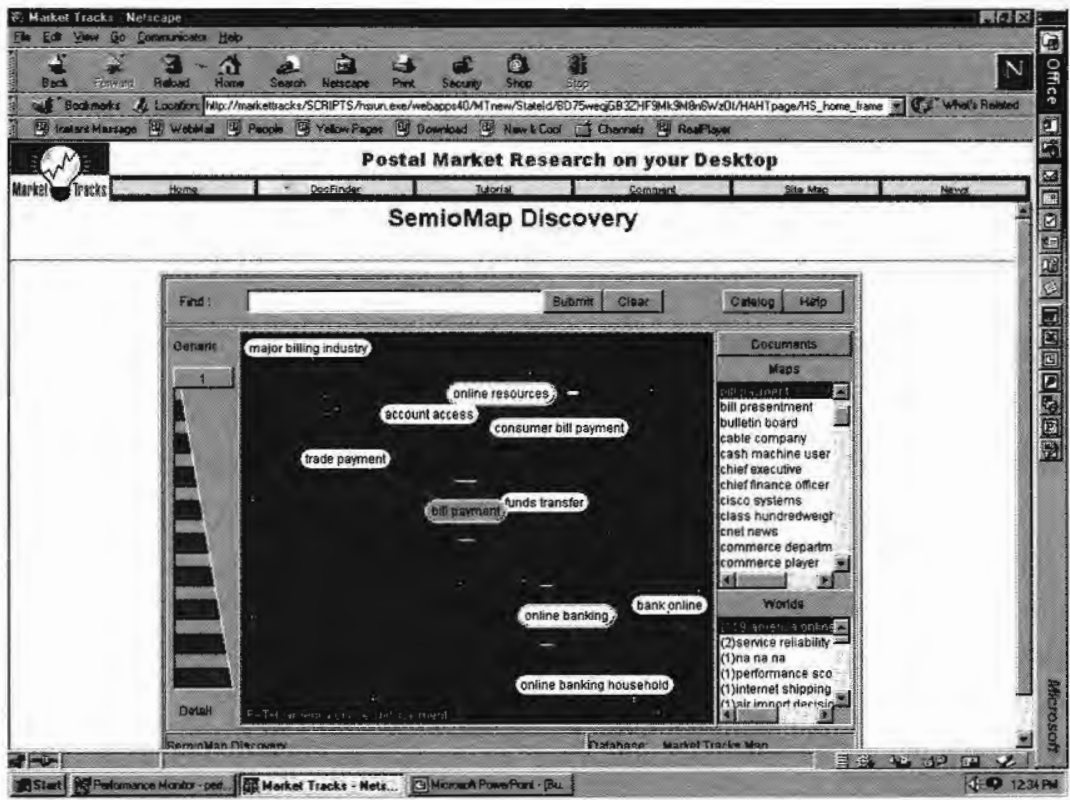

Figure - 5

Figure 5 shows the alternative display of a map.

The preceding three examples of different taxonomies are addressed either at the processing stage of information input, or at the display of results. However, the modern enterprise faces the whole range of problems listed above and must consider all the new approaches being promoted by the suppliers. The prime need to make information easily accessible to its staff through the Enterprise Information Portal or other channel is often compounded by large throughputs and legacy data. Increasingly, there is also pressure to provide maps and user guidelines to the repositories and their contents, which may be numerous and include both internal and external sources. This may introduce the deceptively simple-sounding word 'mapping' that, in fact, indicates the need for a huge amount of intellectual human effort. 
The need for considerable human intervention was a major finding from the research conducted last year by TFPL Ltd., as was the multiplicity of information architectures employed by the large organisations [1].

Corporate taxonomies : One manifestation of such different architectures includes a super-thesaurus, as used by Glaxo Wellcome (now GlaxoSmithKline) wherein a number of existing thesauri have been loosely merged and each term carries the addresses of any corporate information repositories using that term (Figures 6 and 7).

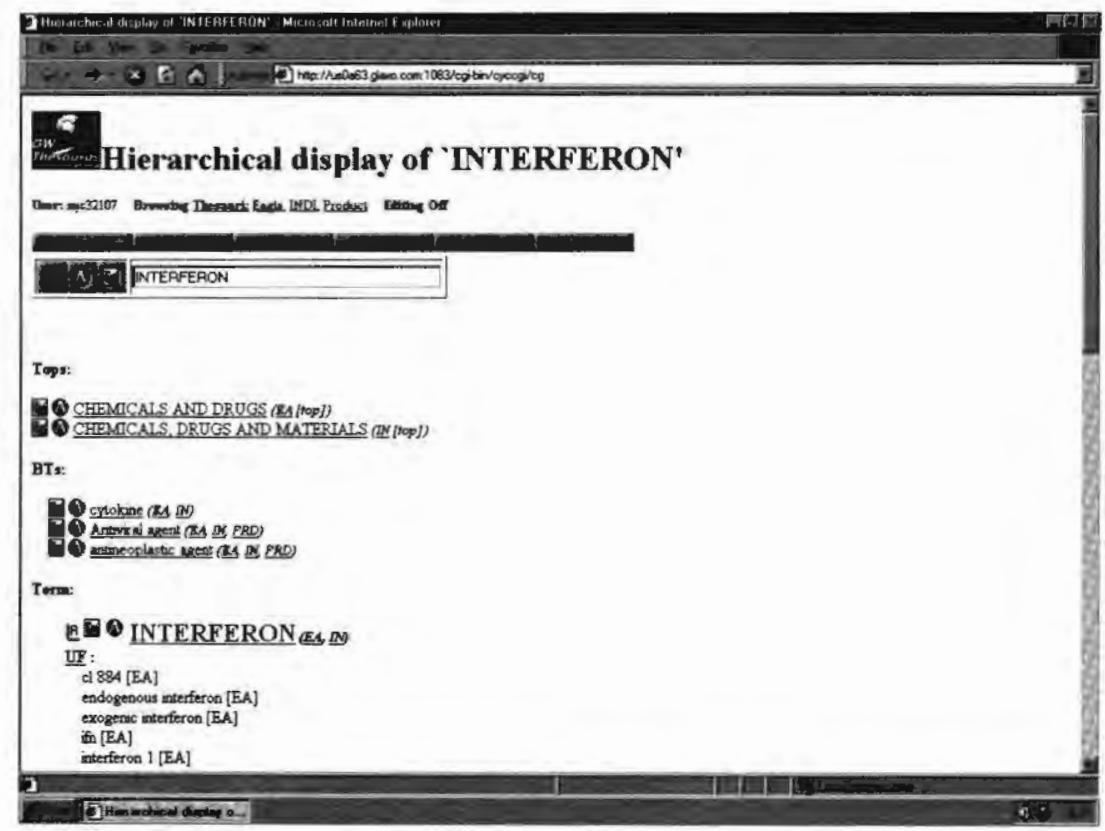

Figure - 6 


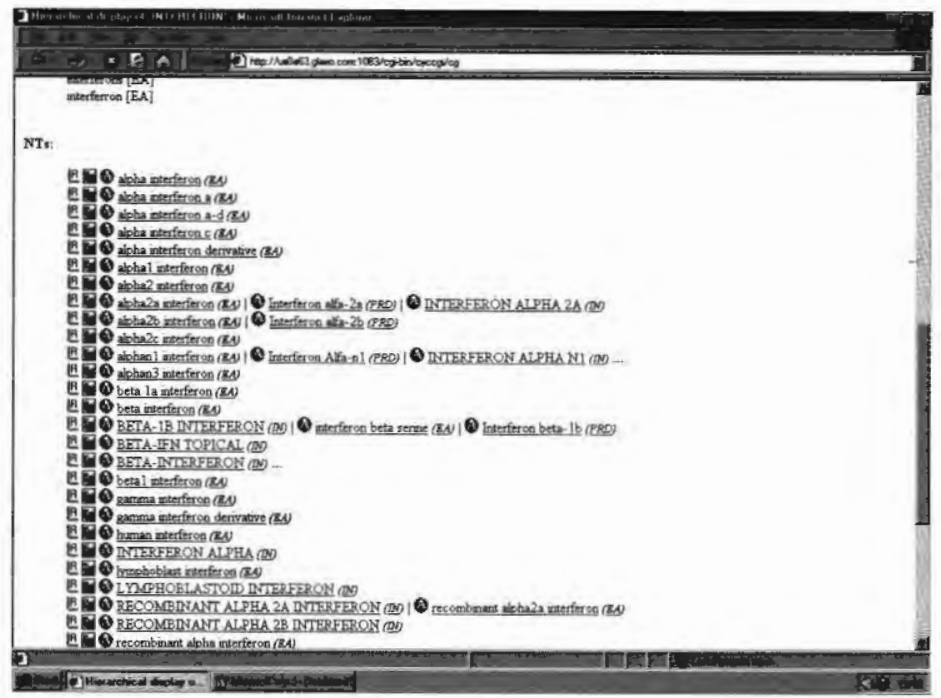

\section{Figure - 7}

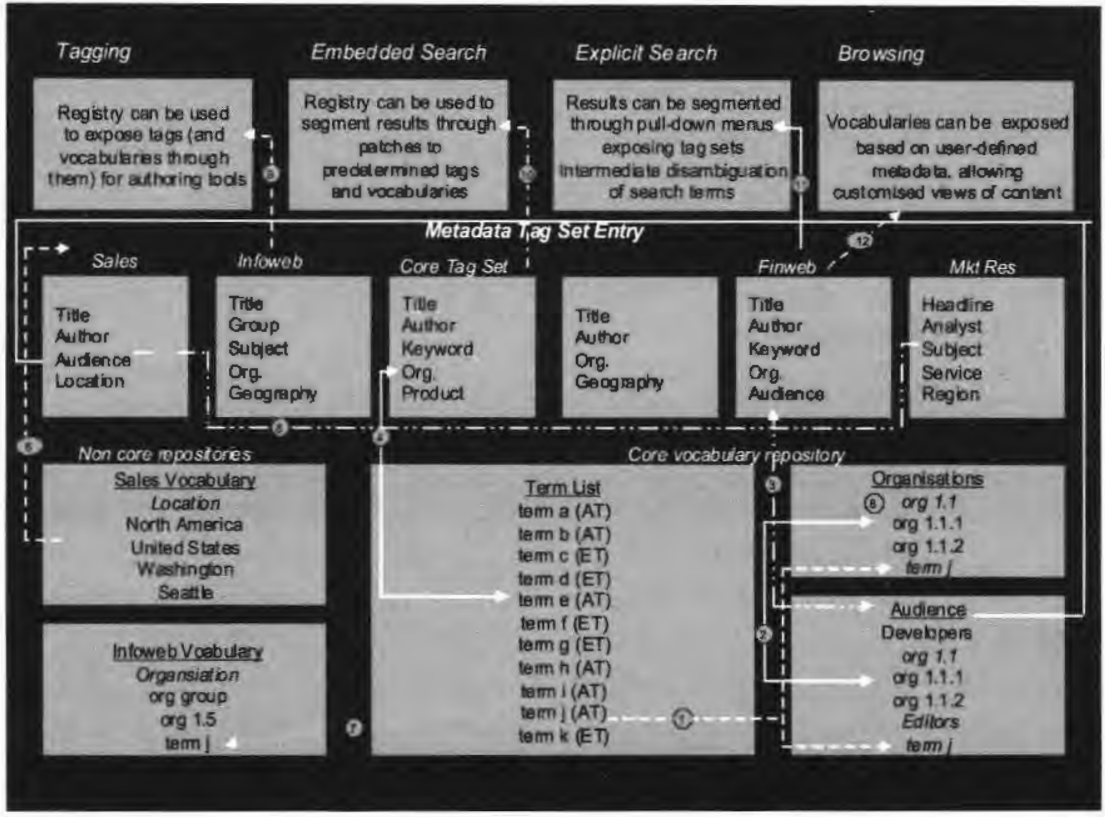

Figure - 8 
This is a huge effort with some 53,500 basic concepts (or lead terms), 201,750 synonyms (remember, this is the pharmaceutical industry with trade name and chemical equivalents round the world), and 443,500 related terms; another is a corporate macrothesaurus containing terms common to the whole enterprise, and to which are hooked microthesauri for specialist areas, an approach used by one of the world leader management consultants; a third is a metadata registry made available by the Microsoft Knowledge Architect Team to portal owners and information providers, containing tagging standards supported by generic terminologies (Figure 8 displays the schema for this system); yet another approach provides high-level "knowledge maps" pointing to the location of relevant repositories, with guidelines on their contents and access paths and protocols; finally there are expertise databases supporting knowledge-sharing through person-to-person connections, often supported by the facility to annotate shared documents or a process of collaborative filtering.

\section{Conclusion}

This short essay has attempted to show that librarians and documentalists are well equipped to understand many of the new words being introduced into their traditional area of work by other professions; but it is vital to understand the nuances, and the ways in which the new terminologies reflect the dominance of information technology and the focus on business processes brought about by the concentration on knowledge management and the desire to exploit intellectual capital. The single word 'taxonomy' was used as an example, but there are many more words to be assimilated, and doubtless, there will be many more to come.

\section{References}

[1] Gilchrist, A. ve K. Peter. (2000). Taxonomies for business: access and connectivity in a wired world. London. TFPL. 